\title{
The Exploration and Practice of the CDIO Engineering Education Mode in Process Control Engineering Curriculum
}

\author{
Wenlei Song \\ College of Electrical and Information Engineering, Beihua University, Jilin, China \\ 787398333@qq.com
}

Keywords: Process control engineering; CDIO; Subject consciousness; Overall process

\begin{abstract}
CDIO engineering education mode conforms to the laws and demands of the contemporary engineering education and this mode is promoted in many colleges and universities both at home and abroad. This paper introduces the thinking and exploration of the process control engineering curriculum in the teaching concept, teaching method and appraisal system under the CDIO mode. In practice, full engineering case teaching and link evaluation system are adopted. At the same time, students who are selected from two classes with the same major in the same year are taught respectively by traditional teaching and the CDIO mode. The students' teaching effects will be followed for one year. According to the effects, statistics shows that the effects of process control engineering curriculum under the CDIO mode are apparently superior to traditional teaching mode. It also proves that this mode can be applied in process control teaching and teaching of other related disciplines.
\end{abstract}

\section{Introduction}

Over the past decades, with the progress of the science, rapid development of the economy and rapid growth of the foreign trade communication, the social demand for engineering graduates has increased. The demand for graduates is not only confined in the level of mastering the relevant knowledge of their own major, but also pays more attention to the ability of controlling engineering project, team communication and cooperation and improving professional level and innovation of graduates. So it is a challenge for our traditional higher engineering education mode which takes the professional knowledge as the center. And the engineering education is also required to lay the theoretical foundation for students, meanwhile enhance the students' ability to control the overall process of the engineering and cultivate students to become engineers who possess the ability of engineering design, organization and coordination and implementation.

It's a severe challenge for higher engineering education in our country to seek a reasonable way to effectively improve the engineering practice ability of students who major in engineering. Many foreign educational research institutions also attach great importance to this issue. In 2000, the CDIO engineering education concept was found by the Massachusetts Institute of Technology and other three overseas universities and also the international cooperation organization which is named after the CDIO was found[1,2].

CDIO engineering education mode is the latest achievement of international engineering education reform in recent years. CDIO represents conceive, design, implement and operate and it takes the life cycle which is from product research to product operation as the carrier to make students study engineering in an initiative, practical and organic connection among courses way. CDIO cultivation outline divides the ability of engineering graduates into four levels which are the basic knowledge of engineering, personal ability, interpersonal team ability and engineering system ability[3]. In 2005, CDIO engineering education was introduced into our country and was highly valued by the Ministry of National Education, and also it was gradually generalized in colleges and universities at all levels.

In the course of automation speciality and measurement and control speciality, the process control engineering is the specialty-oriented course which takes the control theory as the foundation, 
takes the satisfaction of manufacturing technique as the requirement and possesses the characteristic of interdisciplinarity. And in this course, the theory is connected with engineering practice closely.

In the teaching process of process control engineering curriculum, two problems are found by teachers.

1)The deficiency of practical knowledge and practical skills of students. Students know less about the production environment, device, instrument and typical process flow of the training field of automation speciality and measurement and control specialty which include metallurgy, chemical industry, electricity and so on. The knowledge and ability which are grasped by students cannot satisfy the demand of the overall process of product, process and system conception, design, realization and operation in the case of the increasing internationalization of the industrial production. The theory unhooks connections with the current engineering demand. Meanwhile, students can't adapt to the demand of leading a team or working in a team easily and also can't adapt to the work demand beyond their own major[4].

2)The deficiency of subjective consciousness of students in the teaching links.

The subjective consciousness of students should be embodied in the whole process of education and also in the whole process of practice education. However, in the process of practice education (especially in internship and course design), students always rely on the guide books from the object of practice to the method of practice because of the limitation of current teaching ways and means. They lack the space of thinking and solving problems independently and lack the independence and creativity of practice. And also through the accumulative effect of the education mode which is dominated by teachers for four years, students can't have subjective consciousness easily.

Because of this deficiency, the aim of engineering education to cultivate excellent engineering talents can't be achieved, the teaching effect is limited, the cultivation and improvement of professional quality of students are limited, the chances of successful employment of students are reduced and the ability of students to adapt to the work demand and work environment quickly is also reduced.

\section{The Design of Teaching Scheme of Overall Process Engineering Cases}

According to the ideas of CDIO engineering education, through the whole process of engineering project, students should possess basic knowledge of engineering, personal ability, interpersonal team ability and engineering system ability[5]. Therefore, the engineering project case which conforms to the practice should be blended in the curriculum. The process of the project includes the preparation of project, the operation of the project and the acceptance check of the project. The corresponding education work should be conducted according to the demand of the syllabus and the situation of each phase of the ongoing project. Therefore, the practical engineering case which is suitable for the undergraduate teaching demand and level should be chosen. Teachers can teach the basic knowledge of course theory, professional knowledge of relevant specialities and engineering technology to students through the explanation and discussion of cases. The various teaching methods and forms can stimulate the enthusiasm of students and improve the various abilities of students. The implementation scheme is shown in Fig. 1. In this process, we should pay high attention to keep the subjective consciousness of students all the time and the learning can't be replaced by teaching. 


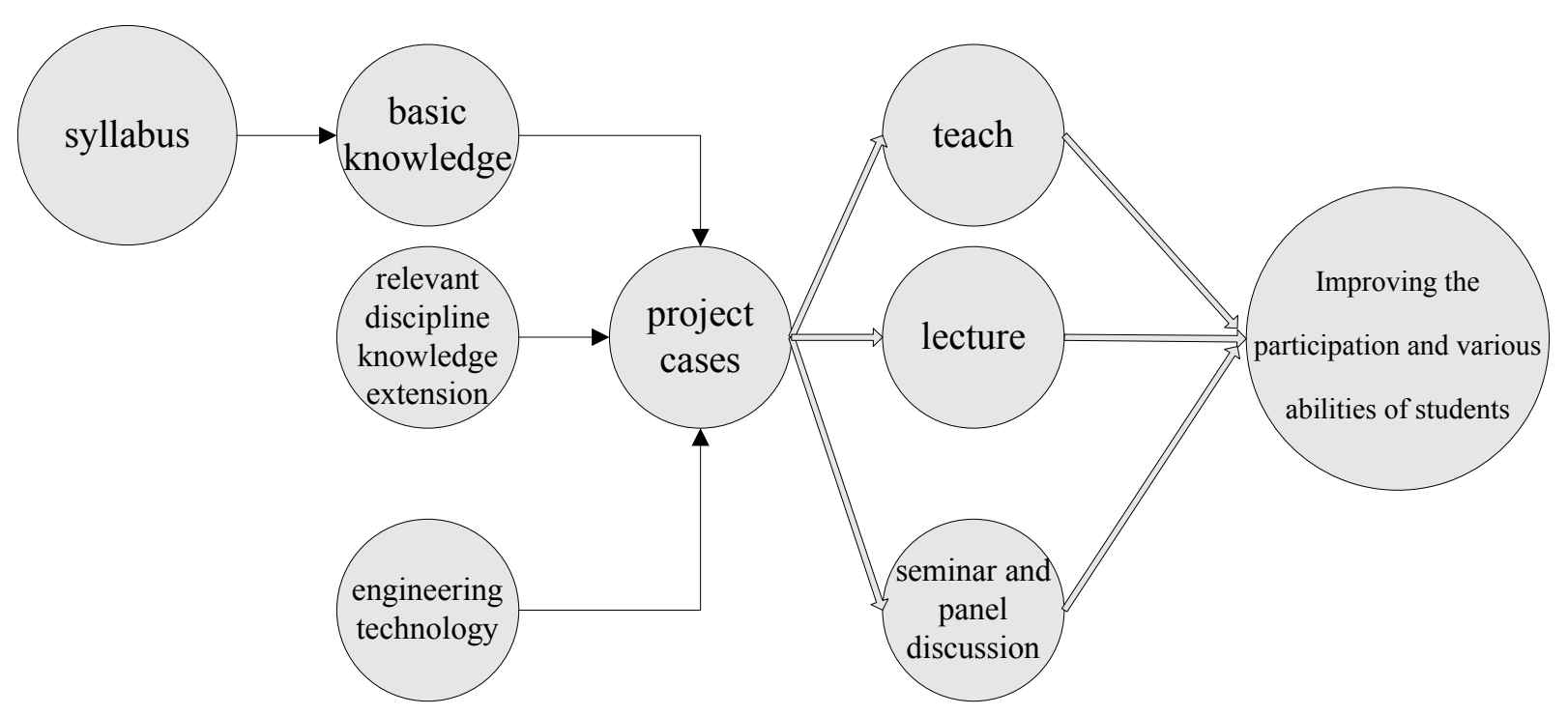

Figure 1. Project case teaching schematic diagram

In this process, engineering project cases are introduced into teaching links in the form of the overall process and the teaching effect of CDIO teaching should be verified through the results of operating the overall process project of CDIO by students. In this link, students are required to complete an engineering project in the form of a team (the relation among teams is competitive) according to the practical operation process of engineering project. The process of project implementation can help students to deepen the understanding and improve the proficiency of the learned theories and skills, and also can help students to form team consciousness and enhance the ability of solving problems independently.

\section{Scheme Implementation}

1)Through the interview for graduates who major in the relevant speciality and the investigation of current situation of college students, combined with the current demand situation and trend of engineering technology talents of relevant industry, according to the ability outline of CDIO engineering education, the limitation of the current teaching mode which takes the speciality as the center is summarized and analyzed.

2)Because of the limitations which exist in figure 1 and according to the concept of CDIO and the successful experience both at home and abroad, the current teaching mode is adjusted, as showen in Fig. 2.

(1) The adjustment of teaching aim and outline

Process control engineering curriculum is a specialty-oriented course. The aim of this course is to make students grasp the basic constitution, working principle, engineering design and implementation method of control system in the process of industrial production, know the characteristics of common typical productive process and the analysis and design method of its control system and preliminarily possess the ability of design, debugging, operating maintenance of process control system. 


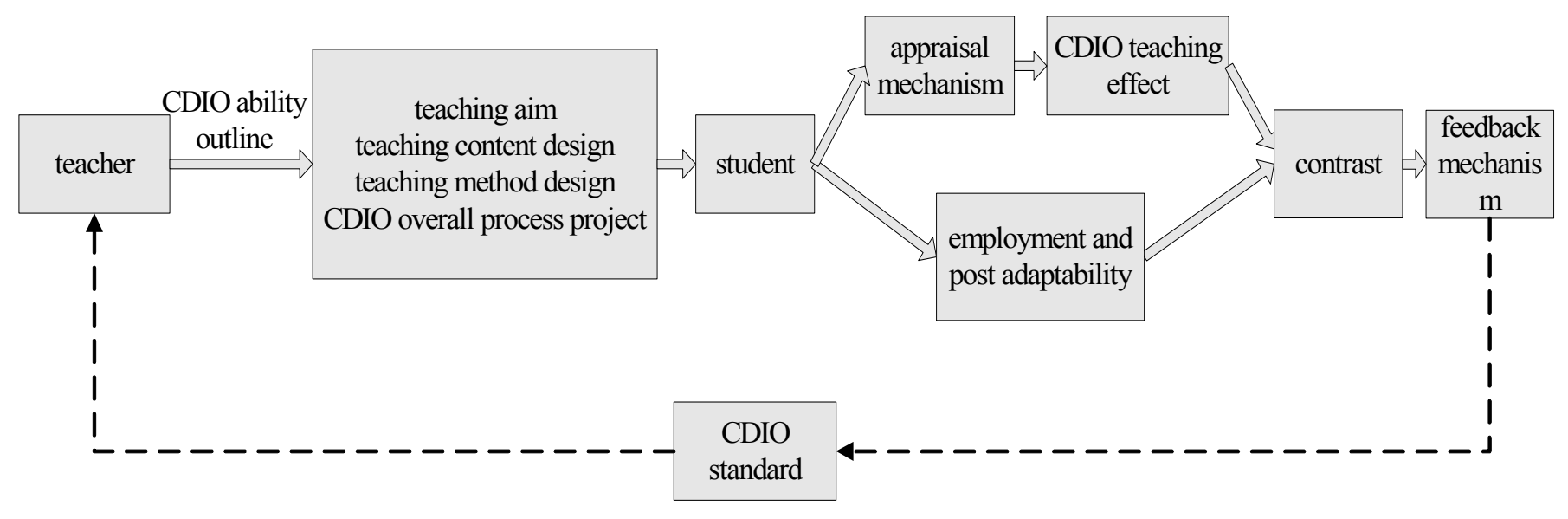

Figure 2. CDIO Teaching scheme implementation diagram

After the CDIO engineering education mode is introduced into the education of this curriculum, the aim of education not only includes the requirement of professional knowledge but also emphasizes the improvement of ability. And students are trained to possess the ability of designing, analyzing, achieving and evaluating the process control system and was also trained to know the overall process of the development of an engineering project. Therefore, the teaching aim and syllabus should be adjusted correspondingly to make the demand and aim of process control system curriculum adapt to the concept of CDIO[6].

(2) The design of teaching content

In order to meet the requirement of adjusted syllabus, the teacher should combine the explanation of theory knowledge with practical cases of engineering project in the teaching process, and according to the analysis and discussion, the teacher should guide student to think and make students establish the concept of the engineering[7]. In the practice link of the course, students are required to complete a team research project which includes the overall process of conception, design, implementation, improvement and exhibition based on the foundation of learning theory knowledge of process control engineering and also students are required to explore the learning and improve four ability in the process of cooperation to make them find and create the fun.

(3) The design of teaching method

Since the CDIO engineering education emphasizes the improvement of the ability of students, it is necessary to increase the time for students to carry out the project. However, the total hours are unchanged, so the class hours must be reduced. In order to guarantee the teaching quality, the traditional teaching method should be adjusted. Adjustments are as follows[9]:

For the easy-to-understand content, students should study in the form of self-study and group discussion. In that way, the ability of independently thinking and solving problems can be cultivated and the team consciousness of students can be improved.

The case teaching and discussion which are in accordance with engineering practice are carried out. Through the introduction of thematic background information, the PPT, video, expert lectures, site visit and other teaching forms should be adopted to encourage the interaction between teachers and students, increase the classroom information, stimulate the interest of students, raise the learning enthusiasm of students, and based on the foundation theory education, enhance the ability of recognizing, analyzing and solving practical problems of students.

Students should be grouped to make the practice of project overall process[10].

Students should be required to read a number of literatures and communicate and discuss periodically to form the complementation of knowledge.

The assessment standard should be established based on feasibility, the proportion of project implementation situation in the score should be increased, and the score of the experiment and 
internship (the overall process practice of the project) should be increased to the $50 \%$ of the total score.

(4)According to twelve standards of CDIO, the teaching effect should be inspected, the feedback system of teaching effect of CDIO engineering education mode should be established, the using experience of CDIO engineering education mode in process control engineering curriculum should be summarized and the shortcomings in CDIO practice should be adjusted.

\section{Results Analysis}

Students in this practice are respectively from measurement control and instrument class and automation major class in the same year. The practice will be conducted in the first semester and the second semester. The amount of students who are taught by CDIO case is 70 . The amount of students who are taught by common case is 75 .

Table 1 The comparative table of the educational effect of the CDIO engineering case education and common engineering education

\begin{tabular}{|c|c|c|c|c|c|c|}
\hline \multirow[b]{2}{*}{$\begin{array}{c}\text { Group } \\
\text { Test data }\end{array}$} & \multicolumn{2}{|c|}{ System design test } & \multicolumn{2}{|c|}{$\begin{array}{c}\text { System } \\
\text { implementation test }\end{array}$} & \multirow{2}{*}{$\begin{array}{c}\text { The course } \\
\text { feedback of } \\
\text { students } \\
\text { (learing effect } \\
\text { satisfaction)\% }\end{array}$} & \multirow{2}{*}{$\begin{array}{c}\text { Aboral } \\
\text { employment } \\
\text { situation }\end{array}$} \\
\hline & $\begin{array}{c}\text { Excellent } \\
\text { rate }\end{array}$ & $\begin{array}{l}\text { Pass } \\
\text { rate }\end{array}$ & $\begin{array}{c}\text { Excellent } \\
\text { rate }\end{array}$ & $\begin{array}{l}\text { Pass } \\
\text { rate }\end{array}$ & & \\
\hline CDIO group & $32 \%$ & $93 \%$ & $45 \%$ & $98 \%$ & $96 \%$ & $64 \%$ \\
\hline Common group & $7 \%$ & $74 \%$ & $11 \%$ & $87 \%$ & $78 \%$ & $47 \%$ \\
\hline
\end{tabular}

As shown in Table 1, based on system design test, system implementation test, the course feedback of students, and aboral employment situation, all indicators in the class that is taught by CDIO engineering case education are superior to other classes'.

\section{Conclusion}

After the reform by CDIO teaching mode, the characteristics of process control engineering are as follows:

The learning interest of students has been stimulated effectively. The level of active learning and enquiry mind of students have been improved obviously.

The team spirit and communication ability of students have been improved. Many students are willing to actively cooperate with other team members to complete the project.

The broad vision of scholarism and engineering technology has raised the innovation enthusiasm of students.

The adaptive speed and level of graduates for the relevant work are higher than before.

\section{References}

[1] P.H. Gu, N.S. Bao: CDIO in China(part one). Research in Higher Education of Engineering. Commun. 3 (2012) 24-40.

[2] P.H. Gu and N.S. Bao: CDIO in China(part two). Research in Higher Education of Engineering. Commun. 5 (2012) 34-45.

[3] L.H. Wu: Exploration and Practice on Innovative IT Talent Cultivation Based on CDIO International Engineering Education Concept. People's Post and Telecommunications Press. Bei Jing,2014,pp.40-45. 
[4] H.X Wang and H. Zeng: Exploration and Practice on Enhancing Course Practice Based on CDIO Laboratory Research and Exploration. Commun. 10(2016) 196-199.

[5] X.L. Xu and M. Liu: Exploration on Measurement and Control of Professional Talent Training Program Based on OBE-CDIO. GuangZhou Chemical Industry. Commun. 4 (2016) 139-142.

[6] J.P. Li: Research on Electronic and Information Engineering CDIO Cultivation System and Curriculum Design Beijing Jiaotong University Press. Bei Jing,2013,pp,81-119.

[7] L.H. Han and Y. Zhou: Engineering Project Teaching Case Development and Application Practice Based on CDIO Concept. Computer Education. Commun. 24 (2015) 139-143.

[8] Q. Zhao and J.P. Du: Teaching Research on Mechanical Engineering Case Based on Innovative Education and CDIO Concept. Science and Public(Science and Education). Commun. 3 (2016) 133.

[9] M.G. Li and Z.W. Zhu: Research on Curriculum System Facing Engineering Process. Research in Higher Education of Engineering. Commun. 4 (2014) 1-5.

[10]DSP Curriculum Teaching Design and Practice Based on CDIO Education Concept. Experimental Technology and Management. Commun. 6 (2014) 223-225. 